\title{
MINERALOGY AND PETROLOGY OF THE BRNJICA GRANITOIDS (EASTERN SERBIA)
}

\author{
N. Vaskovic ${ }^{1}$, A. Kuroneos ${ }^{2}$, G. Christofides ${ }^{2}$, D. Sreckovic-Batocanin ${ }^{1}$ and D. \\ Milovanovic ${ }^{1}$ \\ ${ }^{1}$ Faculty of Mining and Geology, Djusina 7, 11000 Belgrade, Serbia and Montenegro, \\ nadavask@eunet.yu. \\ ${ }^{2}$ Department of Mineralogy-Petrology-Economic Geology, School of Geolofy, Aristotle University \\ of Thessaloniki,54621,Thessaloniki, koroneos@geo.auth.gr, christof@geo.auth.gr
}

\begin{abstract}
The Variscan Brnjica granitoids in East Serbia, occurring in the Kucaj Terrane of the CarpathoBalkanides, are composed of hornblende - biotite tonalite (TON), biotite granodiorite (GRD), twomica granite (TMG) and leucogranite (LG). The rocks analyzed are slightly peraluminous. A preplate collision tectonic environment is supported based on the R1-R2 discrimination diagram. A two-step mixing plus fractional crystallization (MFC) process is considered responsible for the evolution of the Brnjica granitoids. In the $1^{\text {st }}$ step, the parental magma (having the composition of the more basic TON) is forming the mineral assemblage $\mathrm{Pl}_{59.6} \mathrm{Bi}_{10.3} \mathrm{Hb}_{10.7} \mathrm{Mt}_{0.7} \mathrm{Tit}_{1.0} \mathrm{Qz}_{17.7}$ by $44 \%$ crystallization, and at the same time is mixed $(r=0.1)$ with a magma similar to TMG to give a melt similar to the composition of the less evolved GRD. In the $2^{\text {nd }}$ step, $60 \%$ crystallization $\left(\mathrm{Pl}_{39.0} \mathrm{Kf}_{1.0} \mathrm{Bi}_{25.0} \mathrm{Zr}_{0.6} \mathrm{Ap}_{1.8} \mathrm{Mt}_{1.4} \mathrm{Tit}_{1.0} \mathrm{Qz}_{30.3}\right)$ of the less evolved GRD and a simultaneous mixing with the same acid magma (TMG) but with higher $r(0.6)$ is needed for the genesis of GRD group. The TON could originate in the crust by melting of amphibolites and basalts under various P-T conditions while the granites could be crustal melts produced by melting of amphibolites, gneisses, graywackes and pelites. Pressure of 2.3 to $4.1 \mathrm{~kb}$ and temperatures from 626 to $813^{\circ} \mathrm{C}$ were calculated for TON, using hornblende and co-existing hornblende and plagioclase compositions respectively.
\end{abstract}

\section{INTRODUCTION}

The Variscan granitoids of East Serbia within the Carpathian-Balkan arc (Fig. 1), form a NNWSSE elongated zone of about $200 \mathrm{~km}$ in length (Fig. 2) that starts from Danube to the north and extends up to the southern slopes of Mt. Stara Planina, at the Yugoslavian-Bulgarian border. The zone comprises eight, relatively large, granitoid plutons (Brnjica, Neresnica, Gornjane, Plavna, Ravno Bucje, Suvodol, Radicevo, Janja), and more than ten small intrusive bodies (Fig. 2). A number of authors assigned the granitoids to the synorogenic sialic magmatism (Petkovic 1960, Pavlovic et al. 1963, Deleo'i et al. 1962, Divljan \& Divljan 1967). Although the East Serbia granitoids were studied by numerous researchers many features concerning magma origin, age, tectonic setting etc. are still unresolved. The age of the plutonites, according to $\mathrm{K}-\mathrm{Ar}, \mathrm{Rb}-\mathrm{Sr}$ and $\mathrm{U}-\mathrm{Pb}$ radiochronological data ranges between 290-310 Ma.

Geotectonicaly the area belongs to the Composite Terrane of the Carpatho-Balkanides (CBCT), comprising five terranes: Vrska Cuka-Miroc (VCMT), Stara Planina-Porec (SPPT), Kucaj (KT), Homolje (HT), and Ranovac-Vlasina-Osogovo (RVOT) (Karamata \& Krstic 1996; Fig. 2). Among them the VCMT, SPPT and KT terranes are the most important regarding the Variscan granite magmatism (Fig. 1 and 2).

According to existins structural and petrological data it is accepted that the origin and intrusion of the Eastern Serbia granitoids and the formation of the East Serbian CBCT were related to the closure of oceanic regions (Karamata \& Krstic 1996). Reported U/Pb, Rb/Sr and KJAr ages of granites in the Carpathian-Balkan arc range from 259 to $342 \mathrm{Ma}$ (Deleon et al. 1962). 
Regarding the Brnjica granitoids (272-259 Ma - Rb/Sr, Deleon et al. 1962) they intruded mainly discordantly the Ripheo-Cambrian metavolcano-sedimentary rocks (Simic 1962). The same author distinguished leucocratic granites (the oldest phase), porphyritic granites, often followed by dykes of aplitic granites and quartz veins (the second phase) and granodiorites (sensu lato), followed by an additional younger dyke phase of fine- to medium-grained granites (the third magmatic phase).

In this paper new mineralogical, petrological and geochemical data are presented and an attempt is made to investigate the origin and evolution of the Brnjica Granitoids (BG), located in the Danube Gorges (Fig. 2), by using major and trace element numerical modelling.

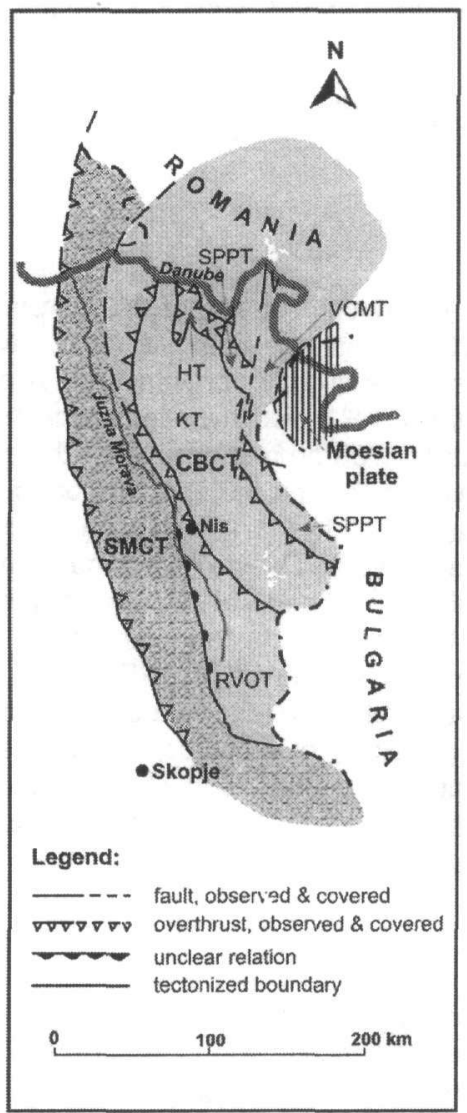

Figure 1. Terranes of East Serbia (after Karamata \& Krstic 1996). See explanation in text.

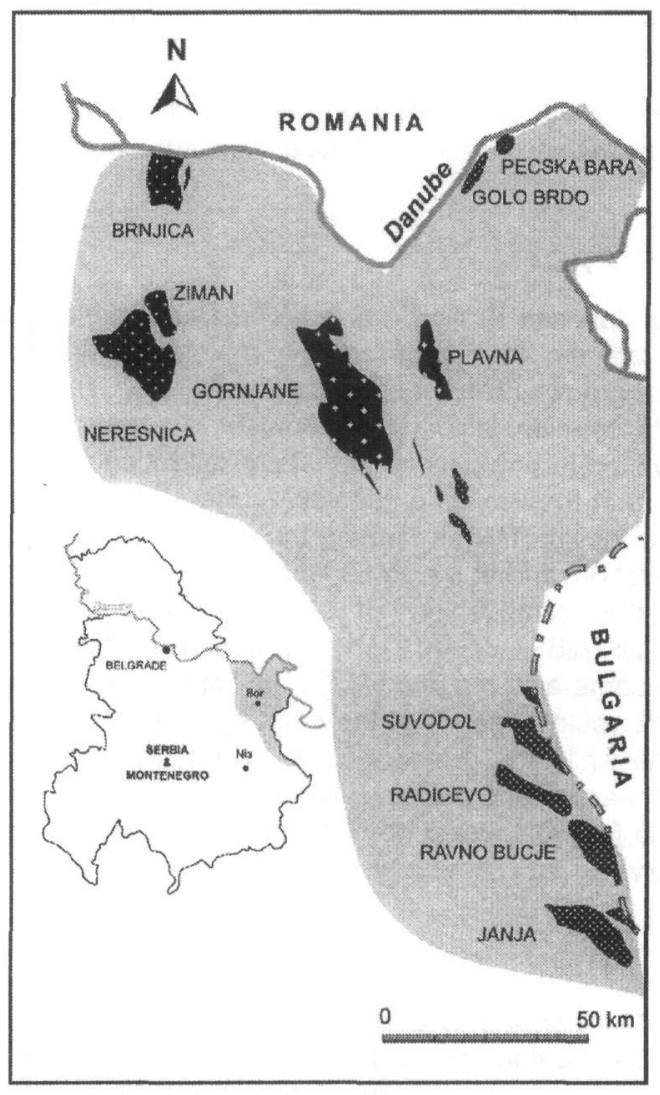

Figure 2. Distribution of Variscan Granitoids in East Serbia.

\section{GEOLOGY AND TECTONIC SETTING}

The Brnjica granitoids occur in the KT (Krstic \& Karamata 1992, Fig. 2), the oldest rocks of which are the Proterozoic Osanica metamorphic rocks, followed by the late Proterozoic to early Cambrian "Green Complex" (Fig. 3). During the Variscan magmatism the Brnjica pluton intruded the above formations, as a late- to post-kinematic intrusion, causing a medium grade thermal metamorphism (Karamata \& Krstic 1996, Vaskovic \& Matovic 1997 and references therein).

The KT is characterized by a complex geological evolution. Its western and eastern boundary is an Alpine eastward thrust. It is composed of the Proterozoic Osanica medium- to high-grade metamorphics, and Late-Proterozoic to Early-Cambrian low-grade metamorphic rocks. From the Upper Ordovician to the Lower Carboniferous, on the crystalline basement, fossiliferous terrigenous sedi- 
ments of the Caledonian-Variscan cycle were deposited in different environments (shallow-marine and deep sea). Small gabbro, diabase and plagiogranite bodies intruded these sediments. They are assumed as intrusions into fracture zones at the margins of an ocean region. The marine regime lasted until the end of the Visean stage, and then, after docking of the KT to the SPPT, the Variscan plutonism took place - the time when the Brnjica granitoids intruded the basement rocks. The PostVariscan sequences comprise terrigenous sediments of Carboniferous and Permian age. Marine ingression at the beginning of the Lower Triassic initiated the Mesozoic Alpine sedimentary cycle. In some depressions and I:ting zones along the reactivated terrane boundaries, flysh was deposited, and in the Upper Cretaceous, volcanic and volcano-sedimentary deposits were formed.

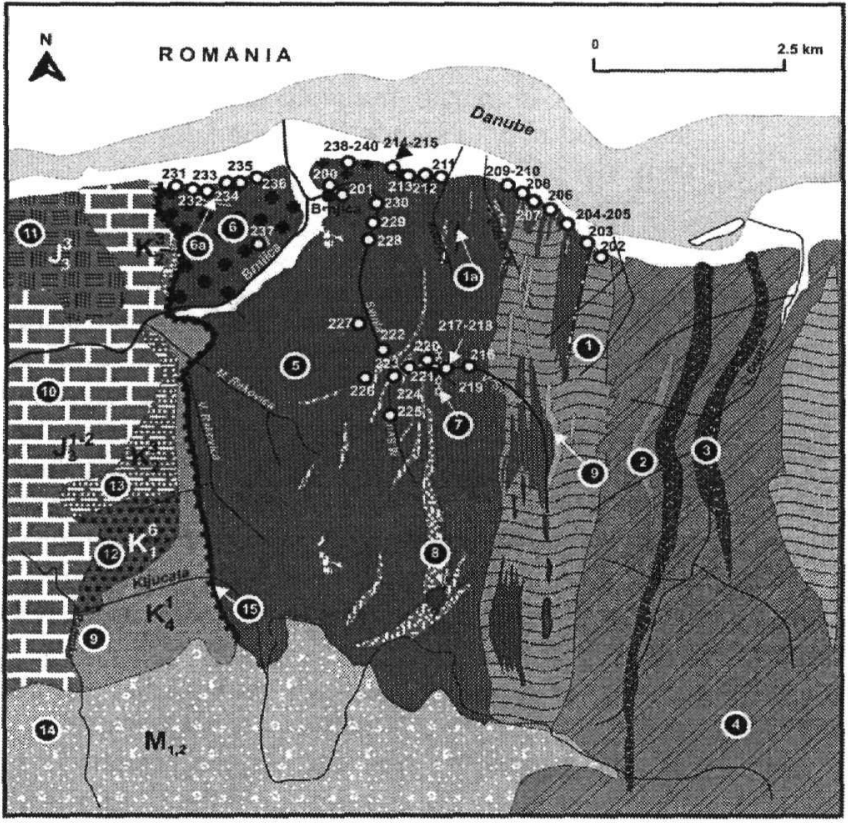

Figure 3. Simplified geological map of the Brnjica granitoids and surrounding area. 1. Gneiss and mica schist (Lower to Middle Proterozoic); 1a. Quartzite 2. Gneiss-granite; 3. Amphibolite (Upper Proterozoic); 4. Greenschist; 5 . Tonalite and Granodiorite; 6. Biotite Granodiorite and Granite; 6a. Aplite; 7. Two-mica granite; 8 . Contact metamorphosed mica schist and gneiss; 9. Leucogranite, aplite, pegmatite; 10. Limestone; 11 . Marly limestone, dolomite and marl; 12 . Marly limestone, marl; 13. Conglomerate, sandstone, sometimes glauconitic and claystone; 14. Conglomerate, sandstone and sandy claystone, marl (Neogen-Miocen); 15. Thrust; 0 - Location of samples analyzed in this study.

\section{PETROGRAPHY}

The Brnjica granitoid pluton has an exposed area of ca. $27 \mathrm{~km}^{2}$ intruding Proterozoic mediumto high-grade gneisses (subordinate mica schist and amphibolite) and Ripheo-Cambrian metavolcano-sedimentary series (Fig. 3) with a variety of green rocks (Kalenic et al. 1980). It comprises ( \pm hornblende)-biotite tonalite (TON), ( \pm muscovite)-biotite granodiorite (GRD), two-mica granite (TMG), and leucogranite (LG) (Fig. 4).

TON builds the main mass of the pluton (Fig. 3). At a few places, close to the contact zone with schists, on the east side and within the roof zone, inhomogeneities resembling mingling and mixing of tonalitic and granitic, mostly leucocratic, material were observed. Furthermore, in this area a lot of contact metamorphosed xenoliths of basement rocks and rare dark grey igneous enclaves of granodiorite and diorite to quartz diorite composition were also noted. Locally, gradual transitions from tonalite to granodiorite or granite with coarse megacrysts of K-feldspar (1-2.5 cm long) exist. The cryptic transition to granodiorite composition was also petrographically noted. The main tonalitic mass is crosscut by younger dykes of two-mica granites of 10 to 500 m thick (Fig. 3 ) or thin pegmatite and aplite dykes (10 cm to $1 \mathrm{~m}$ thick). Typical mineralogy is, plagioclase, quartz, Kfeldspar, biotite, hornblende and apatite, zircon, xenotime and monazite as accessories. Sericite and chlorite are also present, in small quantity, as secondary minerals.

GRD occupies an area of about $1 \mathrm{~km}^{2}$ in the northwestern part of the main mass (Fig. 3 ). In places, transitions to granite are found. It is composed of coarse-grained rocks with large, mostly euhedral K-feldspar megacrysts, plagioclase and quartz. Biotite is the only ferromagnesian mineral. 
Late and/or subsolidus muscovite is also present in small quantities although some grains have features of primary muscovite. Accessory is apatite, zircon, monazite and magnetite.

TMG occurs in the form of dykes of 10 to $500 \mathrm{~m}$ thick, intruding the TON and GRD (Fig. 3). Generally, TMG is represented by medium- to coarse-grained rocks. TMG rocks are also found in the area close to the eastern contact zone of the mass with the crystalline schist (Fig. 3). At a few places, mixing of leucogranitic and tonalitic material was observed. Typical mineralogy is Kfeldspar, plagioclase, quartz, biotite and muscovite with small amounts of accessory apatite, zircon and monazite and secor,dary sericite and chlorite.

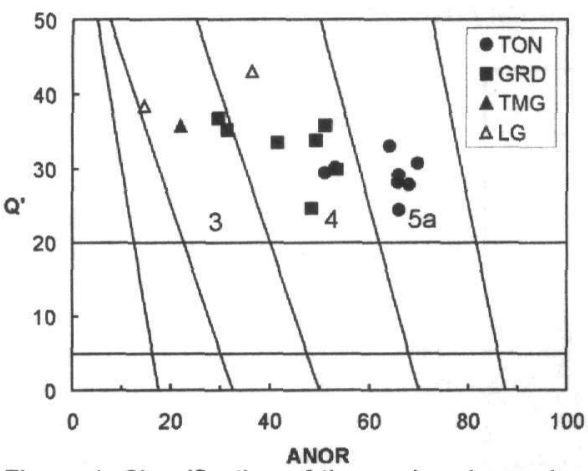

Figure 4. Classification of the analyzed samples of the Brnjica granitoids on the Q-ANOR diagram of Streckeisen \& Le Maitre (1979). 3 - granite; 4 - granodiorite; 5 a - tonalite.

LG appears as thin elongated bodies at the eastern margin of the pluton, intruding concordantly gneisses (Fig. 3). The rocks are composed of Kfeldspar, plagioclase, quartz and muscovite. Apatite, zircon, monazite, magmatic epidote, allanite, titanite and opaques, mostly magnetite, occur as accessories.

\section{MINERALOGY}

Amphibole (1.5 - 5.6 vol. \%) occurs as subhedral to euhedral crystals up to $0.5-1.25 \mathrm{~mm}$ long. Microprobe analyses show that amphiboles from the marginal part of the main pluton mass are magnesio-hornblende. Weak zoning within individual grains is reflected by enrichment of $\mathrm{Ti}$ in the core and fluctuation of $\mathrm{Si}$ and $\mathrm{Al}^{\mathrm{IV}}$ between core and rim, marked by decrease of $\mathrm{Al}$ and increase of $\mathrm{Si}$ in the middle or vice versa. Based on Schmidt's (1992) Al-in-hornblende geobarometer and Holland \& Blundy's (1994) geothermometer, pressure of 2.3 to $4.1 \mathrm{~kb}$ and temperatures up to $813^{\circ} \mathrm{C}$ were calculated for the TON.

Biotite (6.5-15.5 vol.\%) occurs interstitially to feldspar and quartz usually making fine- to medium-grained oval or elongated segregations up to $1 \mathrm{~cm}$ across, sometimes associated with few grains of amphibole. Apatite, zircon, opaques (mostly magnetite), and idiomorphic crystals of titanite appear as inclusions in biotite. Individual flakes are up to $0.5-3 \mathrm{~mm}$ long. In the TON, developed in the roof zone and close to the contact zone, biotite is the main ferromagnesian phase as well as in GRD and TM.j. In porphyritic amphibole-bearing TON it occurs as fine-grained late-stage groundmass mineral up to $0.25 \mathrm{~mm}$, usually forming elongated, occasionally foliated segregations, and as phenocrysts up to $1.5 \mathrm{~mm}$ long. Biotite from TMG $(2-8 \mathrm{vol} . \%)$ is dark yellow to reddish brown, euhedral to subhedral up to $0.1-0.6 \mathrm{~mm}$ or $1-2 \mathrm{~mm}$ long. The analyzed biotites classify as Fe-biotites. $\mathrm{X}_{\mathrm{Mg}}$ ranges from 0.41 to 0.50 . On the discrimination diagrams after Abdel-Rahmann (1994) plot in the calc-alkaline field (Fig. 5).

Muscovite ( 1-5 vol. \%) occurs as primary idiomorphic or secondary flakes, commonly 0.15 to $0.6 \mathrm{~mm}$ long and rarely up to $1.25 \mathrm{~mm}$, emplaced between feldspar or intergrown with biotite in TMG, GDR and LG. Sometimes it forms fine-grained elongated segregations. According to their chemical composition s>me grains are $\mathrm{TiO}_{2}$-rich (1.96-3.27 wt.\%). The analysed white micas have fengitic composition slightly approaching the muscovite end-member. The fengite component ranges from 4 to $18 \%$. $\mathrm{X}_{\mathrm{Mg}}$ ranges from 0.32 to 0.62 . The mean composition of muscovite suggests that biotites with high $\mathrm{Al}$ content coexist with muscovite close to the ideal composition.

Quartz (TON and GDR, 21-26 vol. \%, LG, 23-29 vol. \%) is xenomorphic, commonly weakly deformed and undulatory. It mostly occurs as interstitial elongated grains up to $0.1-2 \mathrm{~mm}$ long.

Plagioclase occurs in all rock-types (50-55 vol. $\%$ in TON, $25-35$ vol. $\%$ in GRD, $22-33$ vol. $\%$ in TMG and $15-24$ vol.\% in LG). It forms euhedral to subhedral prismatic crystals, which sometimes enclose tiny flakes of biotite, apatite, zircon and rarely monazite. In GRD and TMG plagioclase is often normally zoned with GRD having higher An\% differences between rim (19-28 An\%) and core (24-38 An\%) than TMG (rim, 24-30 An \%; core, 26-31 An\%). TON plagioclases show normal and oscillatory zoning either normal (core, 28-32 An\%; intermediate, 30-38 An\%; rim, 21-35 An\%) or reverse (core, $30 \mathrm{An} \%$; intermediate, $29 \mathrm{An} \%$; rim, $34 \mathrm{An} \%$ ). 

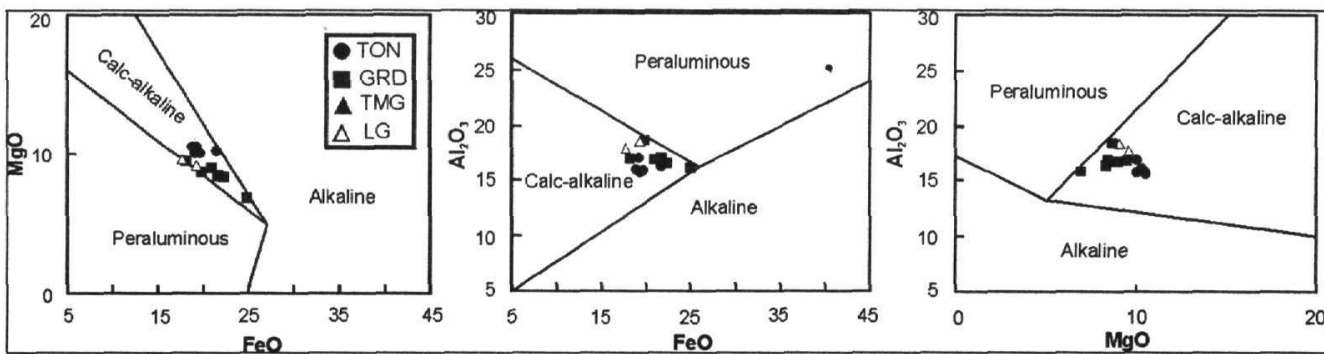

Figure 5. Plot of the biotites from the Brnjica granitoids on the Abdel-Rahman (1994) discrimination diagrams.

K-feldspar is the main constituent in GRD (30-43 vol.\%), TMG (35-45 vol.\%) and LG (42-56 vol. $\%$ ), while in TON is present in small quantities (1.5 to 5.5 vol.\%), although in rocks having only biotite as the ferromagnesian mineral is higher. It is mostly microcline perthite. Large grains enclose plagioclase and biotite. Its mean composition ranges from $\operatorname{Or}_{95} A b_{5}$ in $T O N$ to $O r_{91} A b_{8}$ in $L G$. Ba content decreases in K-ieldspar from TON (0.91-1.78 wt. \%) to LG (0.40 wt. \%).

\section{GEOCHEMISTRY}

The chemical composition of the analyzed rocks of Brnjica pluton is shown in table 1 while selected major and trace element variation diagrams are depicted in figure $6 . \mathrm{SiO}_{2}$ in TON and GRD ranges from 64.2 to $68.2 \mathrm{wt}$ \% and from 68.9 to $72.5 \mathrm{wt} \%$ respectively, in TMG is $73.8 \mathrm{wt} . \%$ and in LG ranges from 75.7 to 75.9 wt. \%. In TON and GRD, $\mathrm{TiO}_{2}, \mathrm{Al}_{2} \mathrm{O}_{3}, \mathrm{Fe}_{2} \mathrm{O}_{3}$ t, $\mathrm{MgO}$ and $\mathrm{CaO}$, decrease with differentiation forming well-correlated trends. Alkalies and $\mathrm{P}_{2} \mathrm{O}_{5}$ are rather scattered in TON. In GRD $\mathrm{Na}_{2} \mathrm{O}$ decreases ar. $\mathrm{K}_{2} \mathrm{O}$ increases. In TMG and $\mathrm{LG}$ most of the elements (e.g. $\mathrm{TiO}_{2}, \mathrm{Fe}_{2} \mathrm{O}_{3} \mathrm{t}$, $\mathrm{MgO}, \mathrm{CaO}, \mathrm{Na}_{2} \mathrm{O}$ ) follow the general trend of GRD. In the $\mathrm{K}_{2} \mathrm{O}$ diagram the TMG sample and one LG sample follow the increasing trend of GRD. TMG and LG have low $\mathrm{P}_{2} \mathrm{O}_{5}$ contents. All samples analyzed are slightly peraluminous ( $A / C N K=0.99-1.25)$, which is in contrast to the TON and GRD biotite chemistry, straddling the boundary between calc-alkaline and peraluminous fields (Fig. 5).

Regarding trace elements, V, Sc, Ga, $\mathrm{Zn}, \mathrm{Sr}$ and $\mathrm{Zr}$ decrease with differentiation in TON and GRD, while $\mathrm{Cu}, \mathrm{Co}$ and $\mathrm{Y}$ are scatter. $\mathrm{Ba}, \mathrm{Rb}$ and $\mathrm{Nb}$ are rather scatter in TON while in GRD the first two elements increase and Nb decreases. TMG generally follows the GRD trend while LG forms crosscutting trends with the latter.

Based on the R1-Rz diagram of Batchelor \& Bowden (1985) most of the Brnjica samples, particularly the TON and GRD ones, plot in field 2 of pre-plate collision granites (VAG) (Fig. 7). The most evolved GRD, the TMG and one LG sample plot in field 6 representing the syn-collision anatectic granites. It must be stressed here that the overlap around this field is predictable, since all granitoids evolve towards minimum melting compositions.

\section{DISCUSSION}

The Brnjica intrusior, is a composite pluton consisting mainly of TON and GRD with subordinate TMG and LG. Biotite composition is more or less the same in TON and GRD with slightly decreasing Mg\# from the first to the latter. This decrease can be explained as the result of a differentiation process in which fractional crystallization is involved. On the other hand oscillatory zoning of plagioclase may imply an open system process in which mixing or assimilation is involved. The Harker diagrams (Fig. 6) show continuous evolutionary trends from the TON to the GRD having no compositional gaps. Moreover, there are no sub-parallel or crosscutting trends, and no compositional overlaps between these two rock-types. Slight changes of the trends for some oxides and trace elements exist at around $68 \% \mathrm{SiO}_{2}$. These observations suggest a possible genetic relation between TON and GRD. The changes of the oxide trends could be simply the result of the crystallizing solid change although a more complicated process cannot be excluded. Similarly, a change in the trend is obvious at around $40 \mathrm{ppm}$ of V (Fig. 8). So, a continuous trend (one step process) cannot explain the trace element data for TON+GRD evolution. The granites (TMG, LG) follow in gen- 
eral the trend of the GRD but no definite conclusions can be drawn, regarding their genetic relationships with them. The presence of some mixing-mingling phenomena in the field supports the idea of an MFC two-step process to explain the TON+GRD evolution. The main idea is that the more basic magma of TON is mixed with an acid one and at the same time is differentiated through fractional crystallization up to the composition of the less evolved GRD (1st step). After that this evolved magma is differentiated by MFC to reach the composition of the more acid GRD samples (2nd step).

The average composition of BRJ208 and BRJ226 has been used as the parental magma composition; the composition of BRJ211D has been used as the evolved magma while sample BRJ101 as the assimilant. It is considered that the composition of the latter approaches a crust-derived magma. The relatively high difference in $\mathrm{SiO}_{2}$ between parental and assimilant magma, the presence of mingling phenomena (the two magmas cannot be mixed), and the absence of high correlation coefficients between the trace elements of TON, require the consideration of a small r-value.

Table 1. Major (wt\%) and trace (ppm) element chemical analyses of the Brnjica granitoids

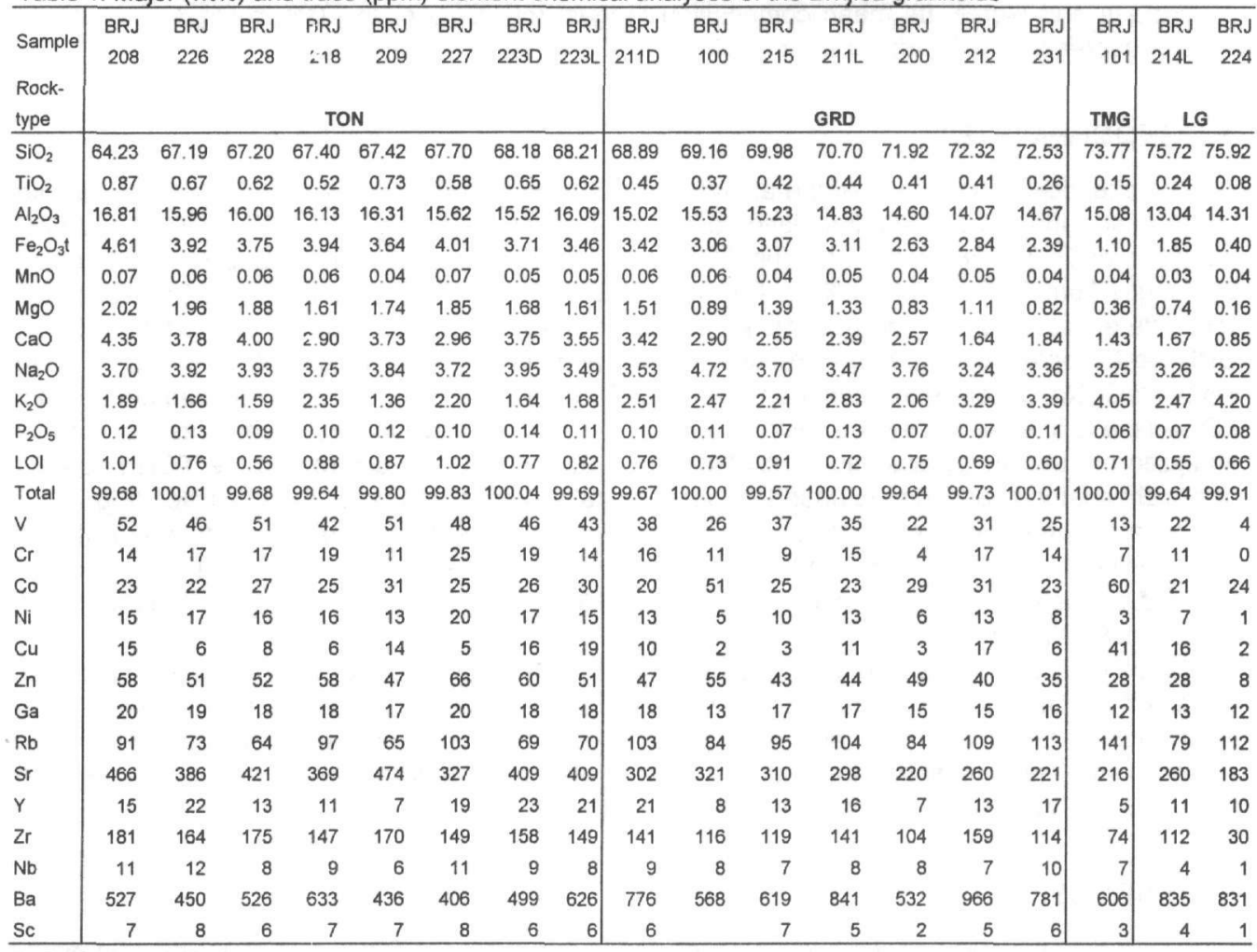

$\mathrm{Fe}_{2} \mathrm{O}_{3}$ t: Total iron as $\mathrm{Fe}_{2} \mathrm{O}_{3}$

Since a low r-value is considered, a major element modelling of a simple fractional crystallization process can help us to estimate the F-value as well as the proportion of minerals crystallized.

The chemical compositional variations are used to determine the mineral phases that control the two steps. The decrease in $\mathrm{Fe}_{2} \mathrm{O}_{3} \mathrm{t}, \mathrm{MgO}, \mathrm{MnO}$ (Fig. 6) with differentiation indicates crystallization of biotite and/or hornblende, and magnetite, while the decrease in $\mathrm{CaO}$ and $\mathrm{Al}_{2} \mathrm{O}_{3}$ shows crystallization of plagioclase and/or hornblende. The decrease of $\mathrm{TiO}_{2}$ indicates the involvement of titanite as well as biotite and/or hornblende. The $\mathrm{K}_{2} \mathrm{O}$ constant behaviour indicates that the involvement of K-feldsp.ars in the evolution of TON was not significant. In the GRD rocks the major element variation trends, except alkalies and $\mathrm{P}_{2} \mathrm{O}_{5}$, are very similar with those of the TON rocks (except the variation degree), and suggest that the fractionating assemblages (except hornblende) in the two rock groups are quite similar. 
$1^{\text {st }}$ step: As crystallizing phases for the major element modelling of this step analyses of $\mathrm{PI}$ (core), $\mathrm{Kf}, \mathrm{Bi}, \mathrm{Hb}$ (core) and Tit from BRJ-208, and $\mathrm{Zr}$, Ap, Mt from the literature (Deer et al. 1992) were used. The model requires $44 \%(F=0.56)$ crystallization of the parental magma resulting to a mineral assemblage, represented by $\mathrm{Pl}_{59.6} \mathrm{Bi}_{10.3} \mathrm{Hb}_{10.7} \mathrm{Mt}_{0.7} \mathrm{Tit}_{1.0} \mathrm{Qz}_{17.7}$, to reproduce the major element composition of the daughter magma. The sum of the squared differences is quite low $\left(\sum d^{2}=0.37\right)$.

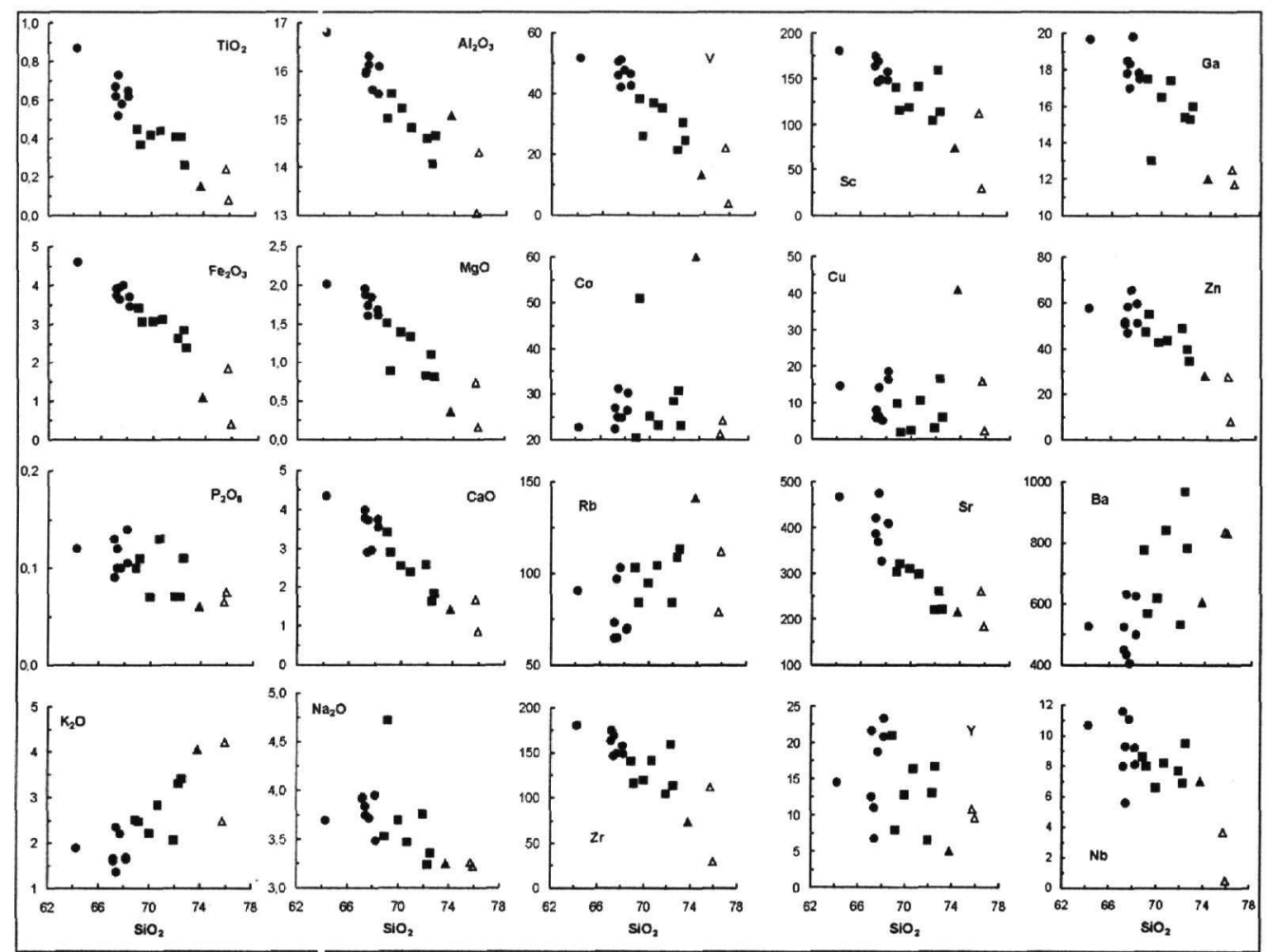

Figure 6. Major ( $w$ \%) and trace $(\mathrm{ppm})$ element variation diagrams for the Brnjica granitoid rocks. Symbols as in figure 4.

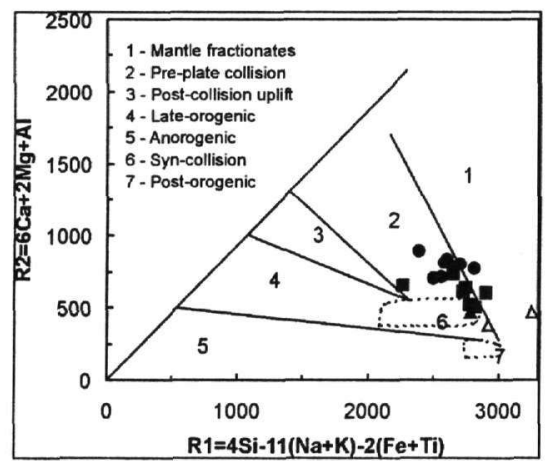

Figure. 7. Plot of the Brnjica granitoids on the R1-R2 discrimination diagram of Batchelor \& Bowden (1985). Symbols as in figure 4.

parental and assimilant magma, the absence of mingling phenomena in GRD as well as the pres-

The mineral assemblage was used along with distribution coefficients $(k d)$ of trace elements from the literature to calculate the $D$ (bulk distribution coefficients) of the trace elements. After that, using the trace element composition of the parental magma (average BRJ208 and BRJ226), the assimilant (BRJ101) as well as the F and $D$ calculated and $r=0.1$, the trace element composition of the evolved magma was estimated using the De Paolo (1981) equation. The results are plotted as a continuous line in the trace element vs. $V$ diagrams along with the analysed samples (Fig. 8).

$2^{\text {nd }}$ step: Using the trace element composition of the resulting magma (similar to BRJ211D) the same process (MFC) was considered to reach the composition of the more evolved GRD samples, represented by BRJ200. A relative high r-value for this step was assumed due to the low difference in silica content of the
ce of mingling phenomena in GRD as well as the pres- 
ence of high correlation coefficients between the trace elements of GRD. In this case the high rvalue makes useless the major element modelling. The $D$ values of the trace elements were calculated for all the combinations of $F(0.7,0.6,0.5$ and 0.4$)$ and $r(0.5,0.6,0.7$ and 0.8$)$. Sixteen combinations were totally used. For each one of these combinations the $D$ value $\left(D_{\text {obs }}\right)$, needed to reach the concentration of the evolved magma starting from the parental, was calculated. Having the $\mathrm{D}$ and the kds, the proportion of minerals crystallized can be calculated using a system of linear equations. After that, the $D$ value for that assemblage was recalculated $\left(D_{\text {calc }}\right)$. Anyone of these calculations leaves a resid' $\lambda$ e $\left[\sum d^{2}=\left(D_{o b s}-D_{\text {calc }}\right)^{2}\right]$. The best of these combinations (sum of the squared differences $=0.000$ ), describing the trends of all the trace elements used, is the one using $F=0.40$ $(60 \%$ crystallization) and $r=0.6$, while the mineral assemblage calculated is $\mathrm{Pl}_{39.0} \mathrm{Kf}_{1.0} \mathrm{Bi}_{25.0} \mathrm{Zr}_{0.6} \mathrm{Ap}_{1.8} \mathrm{Mt}_{1.4} \mathrm{Tit}_{1.0} \mathrm{Qz}_{30.3}$. Then, using the trace element composition of the parental magma (similar to BRJ211D), the assimilant (BRJ101) and F, D and r-values calculated from the above-mentioned system, the trace element composition of the evolved magma was estimated. The results are plotted as a dashed line in the trace element vs. V diagrams (Fig. 8).
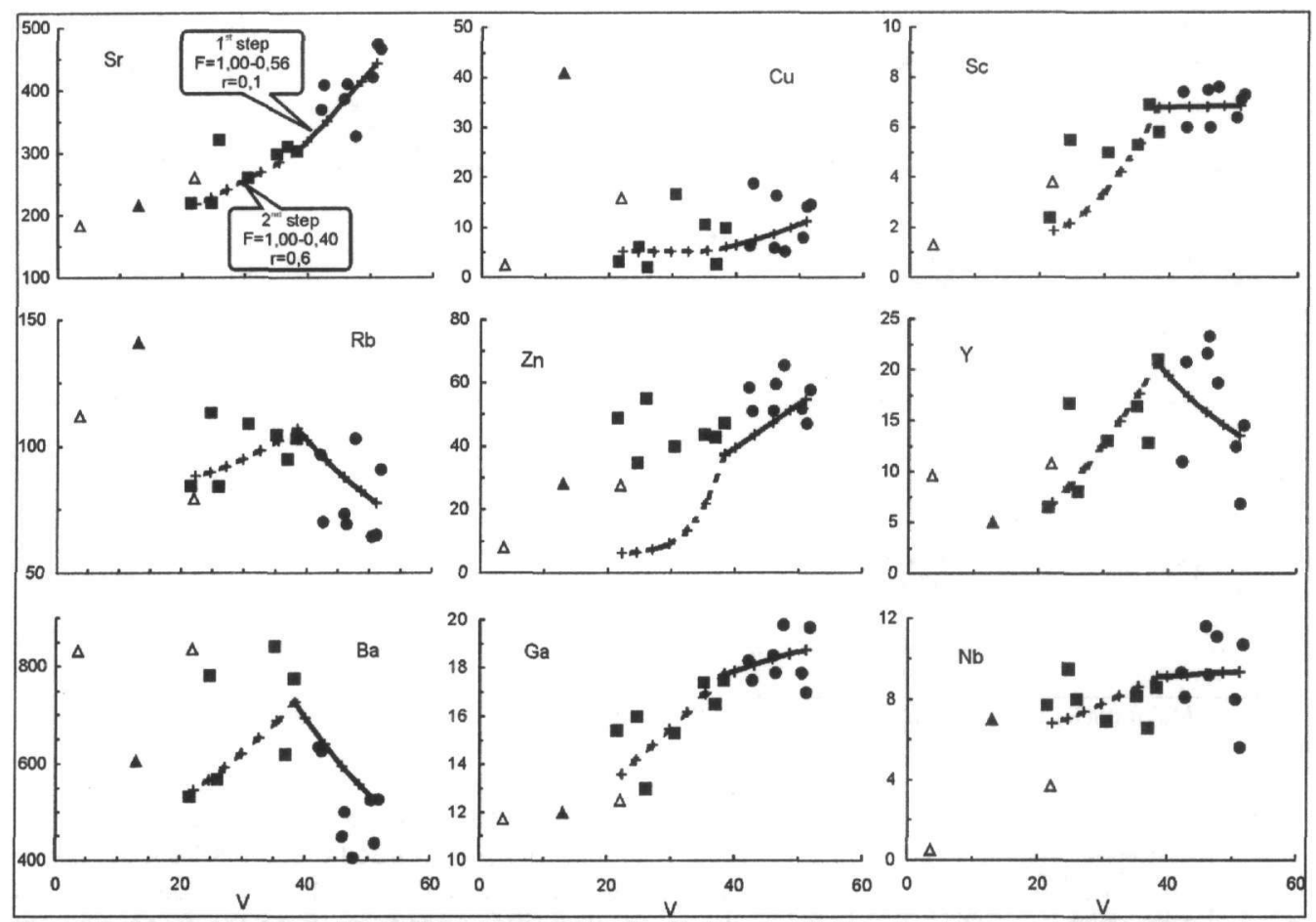

Figure 8. Trace element vs. $V$ variation diagrams for the Brnjica granitoid rocks. Lines represent calculated concentrations of the trace elements in the two step MFC evolution process. Symbols as in figure 4.

The silica-rich charaster of the rocks and the absence of genetic relations with rocks having basic compositions favours, without ruling out an involvement of a mantle-derived magma, an origin by crustal melting under various P-T conditions. Assuming such a process for the production of the melts that gave the rocks investigated, experimental compositions from a database formed from the literature, were used for comparison. The experimental compositions are the results of melting experiments, which have been carried out on rocks representing the composition of the crust (tonalites, gneisses, basalts, andesites, amphibolites, pelites, greywackes) under various P-T conditions, producing melts with variable $\mathrm{SiO}_{2}$ content. Selected experimental melts, having similar compositions with the analyzed rocks, plot on the diagram $\mathrm{Al}_{2} \mathrm{O}_{3}-\left(\mathrm{Na}_{2} \mathrm{O}+\mathrm{K}_{2} \mathrm{O}+\mathrm{CaO}\right)-\mathrm{Na}_{2} \mathrm{O}+\mathrm{K}_{2} \mathrm{O}-$ $\mathrm{CaO}+\mathrm{FeO}+\mathrm{MgO}$ of figure 9 , along with the composition of the TON, TMG and LG. The diagram shows that a variety of rocks could give crustal melts, similar to the investigated rocks. In particular, rocks of amphibolitic composition melted under pressure of $16 \mathrm{kbar}$ and temperature of $1000-1030$ 
${ }^{\circ} \mathrm{C}$ (Rapp et al. 1991), and basaltic composition, melted under pressure of 10-22 kbar and temperature of $1025-1100{ }^{\circ} \mathrm{C}$ (Rapp \& Watson 1995) can produce melts with silica content ranging between about 61 and 67 wt \%, which are similar to TON or have slightly lower silica content.

The TMG and LG could be the results of melting of amphibolites $\left(P, 3 \mathrm{kbar} ; \mathrm{T}, 900{ }^{\circ} \mathrm{C}\right.$; Beard \& Lofgren 1991), gneisses (P, 5-14 kbar; T, 800-1025 ${ }^{\circ} \mathrm{C}$; Holtz \& Johannes 1991; Skjerlie \& Johnston 1993; Skjerlie et al. 1993; Beard et al. 1994), graywackes (P, 0.3-5 kbar; T, $840-1040{ }^{\circ} \mathrm{C}$ (Patino Douce \& Beard 1996; Montel \& Vielzeuf 1997), as well as pelites (P, $10 \mathrm{kbar} ; \mathrm{T}, 850-925$ ${ }^{\circ} \mathrm{C}$; Skjerlie et al. 1993; Dickering \& Johnston 1998).

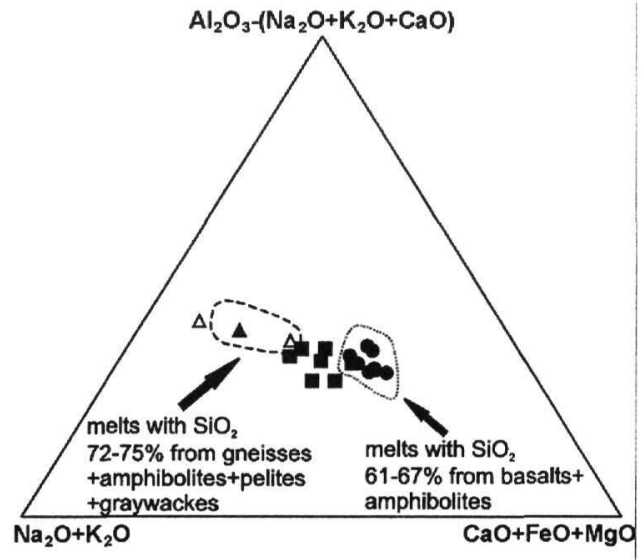

Figure. 9. Plot of the Brnjica granitoids on the $\mathrm{Al}_{2} \mathrm{O}_{3}$ $\left(\mathrm{Na}_{2} \mathrm{O}+\mathrm{K}_{2} \mathrm{O}+\mathrm{CaO}\right)-\mathrm{Na}_{2} \mathrm{C}+\mathrm{K}_{2} \mathrm{O}-\mathrm{CaO}+\mathrm{FeO}+\mathrm{MgO}$ diagram. Fields represent experimental melts. See text for explanation. Symbols as in figure 4.

\section{CONCLUSIONS}

The Brnjica intrusion is a composite pluton consisting of TON, GRD, TMG and LG. Febiotite is the main ferromagnesian constituent in all rock-types except LG. Magnesiohornblende is present, in small quantities, only in TON. Muscovite is $\mathrm{TiO}_{2}$-richer in GRD and TMG relative to LG. Plagioclase, often exhibiting normal and oscillatory zoning, ranges from $A n_{16}$ to $A n_{38}$

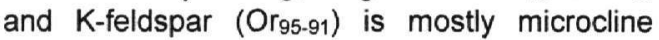
perthite. Minimum crystallization pressure of 2.3 to $4.1 \mathrm{~kb}$ and temperatures from 626 to $813^{\circ} \mathrm{C}$ were calculated, from co-existing hornblende and plagioclase in the TON.

All major elements, except alkalies, decrease with differentiation, defining well-correlated trends. The rocks analyzed are slightly peraluminous although the biotite chemistry is consistent with a calc-alkaline character. A pre-plate collision tectonic environment is supported based on the R1-R2 discrimination diagram.

A two-step mixing plus fractional crystallization (MFC) process is considered responsible for the evolution of the Brnjica granitoids. The MFC process has been modelled by means of major elements least squares petrographic mixing calculations $\left(1^{\text {st }}\right.$ step only) as well as trace elements (both steps). For the $1^{\text {st }}$ step, $44 \%$ crystallization of the mineral assemblage $\mathrm{Pl}_{59.6} \mathrm{Bi}_{10.3} \mathrm{Hb}_{10.7} \mathrm{Mt}_{0.7} \mathrm{Tit}_{1.0} \mathrm{Qz}_{17.7}$ from the parental magma (having the composition of the more basic TON), mixed with a magma similar to TMG with $r=0.1$, is needed to reproduce the composition of the less evolved GRD. In the $2^{\text {nd }}$ step, $60 \%$ crystallization $\left(\mathrm{Pl}_{39.0} \mathrm{Kf}_{1.0} \mathrm{Bi}_{25.0} \mathrm{Zr}_{0.6} \mathrm{Ap}_{0.8} \mathrm{Mt}_{1.4} \mathrm{Tit}_{1.0} \mathrm{Qz}_{30.3}\right.$ ) of the latter and a simultaneous mixing with the same acid magma but with higher $r(0.6)$ is needed for the genesis of GRD group.

The TON could originate in the crust by melting of amphibolites and basalts under various P-T conditions while the granites could be crustal melts produced by melting of amphibolites, gneisses, graywackes and pelites.

\section{ACKNOWLEDGEMENTS}

Thanks are due to Dr. E. Kotali and Dr. Th. Daflos for rock analyses, and Dr. E. Pavlidou and Dr. L. Papadopoulou for microprobe mineral analyses. Thanks are also due to Prof. S. Karamata for review of the manuscript and helpful discussions.

\section{REFERENCES}

Abdel-Rahman, A. F. M. 1؛94: Nature of biotites from alkaline, calk-alkaline and peraluminous magmas. J. Petrol., 35, 525-1029. 
Batchelor, R.A. \& Bowden, P. 1985: Petrogenetic interpretation of granitoid rock series using multicationic parameters. Chem. Geol. 48, 43-55.

Beard, J.S. \& Lofgren, G.E. 1991: Dehydration melting and water-saturated melting of basaltic and andesitic greenstones and amphibolites at 1,3 and $6.9 \mathrm{~kb}$. J. Petrol. 32, 365-401.

Beard, J.S., Lofgren, G.E., Sinha, A.K. \& Tollo, R.P. 1994: Partial melting of apatite- bearing charnokite, granulite and diorite: Melt compositions, restite mineralogy and petrologic implications. J. Geoph. Res. 99, 2159121603.

De Paolo, D.J. 1981. Trace element and isotopic effects of combined wall-rock assimilation and fractional crystallization. Earth Planet Sci. Letters, 53, 189-202.

Deer, W.A., Howie, R.A. \& Zussman. J. 1992: An introduction to the rock-forming minerals. $2^{\text {nd }}$ edition. Longman. 696pp.

Deleon G., Lovric, A. \& Cervenjak, Z. 1962: Some data on the age of granitoid rocks and some mineralization within Carpatho-Balkanides in the East Serbia. Referati V Savetovanja geologa FNRJ, Beograd, 59-62 (in Serbian).

Divljan, M. \& Divljan, S. 1967: Granitoids of the Yugoslav part of the Carpatho-Balkanides in the East Serbia. VIII Congress of Carpathian-Balkan Geological Association - Geological review of Carpatho-Balkanides, Beograd, 27-29 (in Serbian).

Holland, T. \& Blundy, J. 1994: Non-ideal interactions in calcic amphiboles and their bearing on amphiboleplagioclase thermomet.y. Contrib. Mineral. Petrol., 116, 433-447.

Holtz, F. \& Johannes, W. 1991: Genesis of peraluminous granites. Experimental investigation of melt compositions at 3 and $5 \mathrm{~Kb}$ and various $\mathrm{H}_{2} \mathrm{O}$-activities. J. Petrol. 32, 935-958.

Kalenic, M., Hadzi-Vukovic, M., Dolic, D., Loncarevic, C. \& Rakic, M. O. 1980: The Explanatory book for the sheet Kucevo. Ed. Savezni geoloski zavod, Beograd, 80p (in Serbian with English abstract).

Krstic, B. \& Karamata, S. 1992. Terranes of theEastern Serbia Carpatho-Balkanides. Comptes rendus des Sciences de la Soc. Serbe de geol., Livre jubilarie (1998-1991), 57-74, Beograd.

Karamata, S. \& Krstic, B. 1996: Terranes of Serbia and neighbouring areas. In "Terranes of Serbia" (Ed. V. Knezevic-Djordjevic \& B. Krstic), Beograd, 25-40.

Montel, J.M. \& Vielzeuf, D. 1997: Partial melting of metagreywackes, II. Compositions of minerals and melts. Contrib. Mineral. Petrol 128, 176-196.

Patino Douce, A.E. \& Beard, J.S. 1996: Effects of $P, f\left(\mathrm{O}_{2}\right)$ and $\mathrm{Mg} / \mathrm{Fe}$ ratio on dehydration melting of model metagreywackes. J. Petrol. 37, $999-1024$.

Pavlovic, S., Sikosek, B. \& Ristic, M. 1963: Geological, tectonical and petrochemical researches of some granitoid rocks in Yugoslavia and their metallogeny. Fond Geoinstituta, Beograd, 100p (in Serbian).

Petkovic, K. V. 1960. Tectonic Map FNRJ. Glas SAN, CCXLIX. Department of the Natural and mathematic sciences, knj. 22, Beograd, 129-144.

Pickering, J.M. \& Johnston, D. 1998: Fluid-absent melting behavior of a two mica metapelite: experimental constraints on the origin of Black Hills granite. J. Petrol. 39, 1787-1804.

Rapp, R.P. \& Watson, E.B. 1995: Dehydration melting of metabasalt at 8-32 kbar: implications for continental growth and crust - mar tie recycling. J. Petrol. 36, 891-931.

Rapp, R.P., Watson, E.B. \& Miller, C.F. 1991: Partial melting of amphibolite/eclogite and the origin of Archean trondhjemites and tonalities. Precambrian Res. 51, 1-25.

Schmidt, M. W. 1992: Amphibole composition in tonalite as a function of pressure: an experimental calibration of the Al-in-hornblende-barometer. Contrib. Mineral. Petrol., 110, 304-310.

Simic, M. 1962. Petrological and structural study of the Brnjica granitoid mass in the NE Serbia. Unpublished $\mathrm{PhD}$. Faculty of Technology University of Zagreb. 215p (in Serbian).

Skjerlie, K.P. \& Johnston, D.A. 1993: Fluid-absent melting behavior of an F-rich tonalitic gneiss at mid-crustal pressures: implications for the generation of anorogenic granites. J. Petrol. $34,4,785-815$.

Skjerlie, K.P., Patino Douce, A.E. \& Johnston, D.A. 1993: Fluid-absent melting behavior of a layered crustal protolith: implications for th,e generation of anatectic granites. Contib. Mineral. Petrol. 114, 365-378.

Streckeisen, A. \& Le Maitre, R. W. 1979: A chemical approximation to the modal QAPF classification of the igneous rocks. N. Jb. Min. Abh., 136, 169-206.

Vaskovic, N. \& Matovic, V. 1997: The Hercynian granitoids of Djerdap (North-East Serbia). Proc. Intern. Symp. "Geology in the Danube Gorges", 130-141. 